This item is the archived peer-reviewed author-version of:

A James Joyce digital library

\title{
Reference:
}

Van Hulle Dirk.- A James Joyce digital library

European Joyce studies - ISSN 0923-9855 - 25(2016), p. 226-246

To cite this reference: http://hdl.handle.net/10067/1326940151162165141 
This is the author's version of an article published by Brill in the journal European Joyce Studies 25 (2016), pp. 226-246. Please refer to the published version for correct citation and content. For more information, see http://booksandjournals.brillonline.com/content/books/b9789004319622s016.

\section{A JaMes JoyCe Digital Library ${ }^{1}$}

\section{DIRK VAN HULLE}

When Raymonde Debray Genette coined the terms exogenesis and endogenesis in $1979,{ }^{2}$ she was well aware of the artificiality of such a division, for - as Pierre-Marc de Biasi later emphasized when he redefined the terms ${ }^{3}-$ it is hard to separate what is external to a writing project and what is internal. According to a recent paradigm in cognitive philosophy, the same goes for the mind. In 1998, Andy Clark and David Chalmers illustrated their "extended mind" theory by means of an example that involved a notebook. ${ }^{4}$ The gist of the argument is that the mind is constituted in an even-handed way by both the brain and the environment; the brain's contributions are not prioritized over those of the environment.

Many Joyceans have intuitively been working with this hypothesis long before the extended mind theory was formulated. The Finnegans Wake notebooks are an excellent example. To paraphrase Louise Barrett, ${ }^{5}$ Joyce could not have written this book had he not borrowed all the brains that he could, distributed in pamphlets, encyclopedias, newspapers and books.

But the extended mind theory is not just applicable to the writer at work. My suggestion is that it applies to the three main dimensions of literary investigation: the dimension of the text, the dimension of its production and the dimension of its reception. The first part of this essay therefore discusses the mechanics of Joyce's exogenetic enterprise from a theoretical, cognitive point of view and thus provides a theoretical framework for the second part, which investigates how this theory can

\footnotetext{
${ }^{1}$ The research leading to these results has received funding from the University of Antwerp's Bijzonder Onderzoeksfonds (TOP BOF) and the European Research Council under the European Union's Seventh Framework Programme (FP7/2007-2013) / ERC grant agreement n 313609.

2 Raymonde Debray Genette, “Genèse et poétique: le cas Flaubert," in Essais de critique génétique, textes d'Aragon, Raymonde Debray Genette, Claudine Quémar, Jean Bellemin-Noël, Bernard Brun, Henri Mitterand (Paris: Flammarion, 1979), 21-67.

3 Pierre-Marc de Biasi, “Qu'est-ce qu'un brouillon? Le cas Flaubert: Essay de typologie fonctionnelle des documents de genèse," in Pourquoi la critique génétique? Méthodes, theories, ed. Michel Contat and Daniel Ferrer (Paris: CNRS Editions, 1998), 31-60.

${ }^{4}$ In Modern Manuscripts: The Extended Mind and Creative Undoing (London: Bloomsbury, 2014) I argue that it may be useful to approach genetic criticism from this cognitive perspective.

${ }^{5}$ Louise Barrett, Beyond the Brain: How Body and Environment Shape Animal and Human Minds (Princeton and Oxford: Princeton University Press, 2011), ix.
} 
This is the author's version of an article published by Brill in the journal European Joyce Studies 25 (2016), pp. 226-246. Please refer to the published version for correct citation and content. For more information, see http://booksandjournals.brillonline.com/content/books/b9789004319622s016.

inform a practical application in a digital tool that may hopefully be of use to the entire community of Joyceans - a James Joyce Digital Library.

\section{The Extended Mind Theory, "laden with the loot of learning"}

Creative processes in literature partly take place in writers' brains, but to a large extent creation and written invention also happen elsewhere. From the vantage point of cognitive philosophy, Richard Menary has suggested that writing is a form of thinking, drawing attention to the role of a writer's interaction with the "environmental vehicle" (the medium he writes with) in the process of cognition. ${ }^{6}$ An appropriate case study to corroborate this hypothesis is Joyce's red-backed notebook MS 47471b, preserved at the British Library, which I will refer to as the "Guiltless" copybook, ${ }^{7}$ because "Guiltless" is the opening word - and much more than that. The word "Guiltless" arguably indicates a conceptual breakthrough in the genesis of Finnegans Wake. It marks the ignition of the engine that made the work "progress." The paradox of drawing attention to someone's guilt by denying it sets in motion what Joyce claimed he wanted to do after Ulysses: write a history of the world. This "Universal history," as it was still called in an early draft ("Guiltless" copybook; British Library MS 47471b, 50r), became a "manyvoiced moodmoulded cyclewheeling history" in the published version ( $F W$ 186.2). But it did so only after Joyce had found the mechanism behind it. He saw history as a game of "Chinese whispers": nobody knows what actually happened; we can only reconstruct it with hindsight, with fragments from hearsay or other traces. In that sense, Joyce's notion of history is exogenetic in nature.

There is a striking similarity with genetic criticism, which tries to reconstruct the writing history in order to study its dynamics. As a consequence, the following sentence from Chapter 3 not only applies to the narrative situation in Finnegans Wake, but is equally applicable to our endeavour to study the text's genesis: "The data, did we possess them are too few to warrant our certitude" ( $F W$ 057.17). The opening part of the sentence is based on a note in notebook VI.B.10: "these data, did

\footnotetext{
${ }^{6}$ Richard Menary, "The Extended Mind," in The Extended Mind, ed. Richard Menary (Cambridge, Massachusetts: MIT Press, 2010), 27-42, esp. 21.

${ }^{7}$ The word "copybook" is employed to distinguis this type of document (containing drafts) from the "notebooks" containing reading notes and paratactic jottings.
} 
This is the author's version of an article published by Brill in the journal European Joyce Studies 25 (2016), pp. 226-246. Please refer to the published version for correct citation and content. For more information, see

http://booksandjournals.brillonline.com/content/books/b9789004319622s016.

we possess them, are too complex" (VI.B.10.039), and Joyce used this line to write one of the first sentences on page 3 of the "Guiltless" copybook: "The data, did we possess them are too few to warrant certitude" (FDV 71; BL 47471b, 03r). In order to reconstruct the writing process, we make use of as many data as we can find - or in terms of the cognitive paradigm discussed above: critics' minds are similarly extended. And in the case of genetic criticism, the manuscripts that were once part of the writer's extended mind (the dimension of the production) are now part of the critic's extended mind (the dimension of the reception). The aim is not to reconstruct "Joyce's mind" at work. Instead, the purpose is rather to study the work at work, the text as a work in progress (the dimension of the text), realizing that literary studies are a balancing act of cultural negotiation between the reader, the author's selfpresentation, the text and the context ${ }^{8}$ and that the cognitive aspect of the writing process (the mind at work) is a hypothesis based on such a negotiation.

Given this interplay between the dimensions of the text, its production and its reception, one of the most remarkable aspects of "Work in Progress" is the way the dimension of the reception is included in the dimension of the text, for Joyce often employed and recycled the criticism of "Work in Progress" in a creative way to give shape to that same work's progress.

\section{The Epigenetic Feedback Loop: Text-Reception-Production-Text}

Thus, each pre-book publication of "Work in Progress" has its own "epigenesis" - the continuation of the genesis after publication. Joyce also recycled criticism and reviews of his previous work in his new work. For instance, the reception of Ulysses led to indignant reactions such as the review "Beauty - and the Beast" by James Douglas in The Sunday Express: "This is a libel on Ireland, for if Ireland were to accept the paternity of Joyce and his Dublin Joyceries, which out-rosse the rosseries of the Parisian stews, Ireland would indeed $[\ldots]$ degenerate into a latrine and a sewer." When he was making excerpts and notes, Joyce immediately changed the "Joyceries" into "Shemeries" (notebook VI.B.06: 117). While he was writing the

\footnotetext{
${ }^{8}$ Luc Herman and Bart Vervaeck, "The Implied Author: a Secular Ex-Communication," Style 45.1: 1128, esp. 19. See also Luc Herman and Bart Vervaeck, "Narrative Interest as Cultural Negotiation," Narrative, 17.1 (2009), 111-129.

${ }^{9}$ Quoted in Vincent Deane, Daniel Ferrer and Geert Lernout, The Finnegans Wake Notebooks at Buffalo: VI.B.6 (Turnhout: Brepols, 2002), 135.
} 
This is the author's version of an article published by Brill in the journal European Joyce Studies 25 (2016), pp. 226-246. Please refer to the published version for correct citation and content. For more information, see

http://booksandjournals.brillonline.com/content/books/b9789004319622s016.

second draft of the portrait of Shem (Book I, chapter 7 of Finnegans Wake) on page 69 recto of the "Guiltless" copybook, he added on the facing verso: "Shem, son of shame Macadamson, you know me \& I knew you! \& all yr Shemeries!” (British Library MS 47471b-68v). Thus, the reception of Joyce's work became part of the text.

The most conspicuous case of criticism feeding into the Wake is probably Wyndham Lewis's series of attacks against Ulysses and "Work in Progress," notably in The Art of Being Ruled and Time and Western Man. ${ }^{10}$ It is remarkable how often Joyce mentioned Lewis in letters to Harriet Shaw Weaver in April 1929. He asked her to send him a copy of Blast 2 (Letters III 188; 12 April 1929) and wondered whether she had seen the latest issue of The Enemy - number 3, containing Lewis's essay “The Diabolical Principle," with a reference to Joyce's "polygluttonous volume (always 'in progress' - Continuous Present)" (Letters III 188).

So when Joyce was revising his tales and wrote to Weaver about Blast and the Enemy in April 1929, he was clearly preoccupied with "the enemy." What he did with this preoccupation was an impressive example of what Patrick Colm Hogan describes as simulation, that is, "what allows us to get some idea of what it might be like to, say, ask the boss for a raise, before actually doing it." ${ }^{11}$ According Hogan there is a direct relationship between simulation and literary imagination: "Insofar as literary particularization is a function of simulation, it is continuous with our ordinary cognitive processes of counterfactual thinking." $" 12$ This mechanism is applicable in the case of Tales Told. Instead of reacting directly to Lewis, Joyce simulated the situation to "get some idea of what it might be like" to be involved in such a polemic. He then particularized this antagonistic situation in different variations on this theme in his "Work in Progress". Arguably the best examples of Joyce's simulation of Lewis's

\footnotetext{
${ }^{10}$ Around the same period, Lewis's novel The Childermass was published (1928). The character of the Bailiff was clearly modeled after Joyce, surrounded by a "tremulous chorus" of "Bailiffites" (The Childermass, London: John Calder, 1965, 174) and "(wailing loudly above the wind) 'We are factors of Time factors of Time!'” (187). The Bailiff tells the tale of how "dear Shaun as ever was comminxed wid Shem" - which is followed by the parenthesis "for he's a great mixer is Master Joys of Potluck, Joys of Jingles, whom men call Crossword-Joys for his apt circumsolutions but whom the gods call just Joys or Shimmy, shut and short' (174). He is "ponderating 'Neggs-in-progress' and 'wirk-on-the-way' in our back office (with Vico the mechanical for guide in the musty labrinths of the latter-days to train him to circle true and make true orbit upon himself)" (175-6). Even the Roth affair seems to be evoked by means of an anagram: "One would have said Thor in person!" (188)

${ }^{11}$ Patrick Colm Hogan, How Authors' Minds Make Stories (Cambridge: Cambridge University Press, 2013), xiii.

${ }^{12}$ Hogan, How Authors' Minds Make Stories, xiii.
} 
This is the author's version of an article published by Brill in the journal European Joyce Studies 25 (2016), pp. 226-246. Please refer to the published version for correct citation and content. For more information, see http://booksandjournals.brillonline.com/content/books/b9789004319622s016.

antagonism towards him are the "two tales of Shem and Shaun." To the extent that the fables of "the Mookse and the Gripes" and "the Ondt and the Gracehoper" can be read as a response to Wyndham Lewis's criticism and to his explicit positioning as "the enemy," Joyce's masterstroke was to take a meta-stance and to present this kind of antagonism as a recurring and continuously unresolved phenomenon, instead of letting himself be forced into the position of the enemy's enemy. ${ }^{13}$

The fables were published as part of Tales Told of Shem and Shaun by the Black Sun Press, owned by Harry and Caresse Crosby. In The Passionate Years, Caresse Crosby recalls their first meeting with Joyce, arranged through Eugene Jolas and Stuart Gilbert, and mentions an interesting detail about the material environment in which "Work in Progress" took shape:

he led us after him across the hall to his bedroom where he dropped to his knees beside the iron bedstead and pulled from under it an ordinary sized but very dilapidated leather suitcase and unlocked it. [...] It was stuffed to overflowing with clippings, bits of paper fully scribbled over, larger sheets of typescript like bulletins that had been five times through the machine, other miscellaneous odds and ends. "This is my desk," he said, on all fours, and smiled up at us through magnifying lenses, for the first time that afternoon. "It is all in here." $" 14$

From a cognitive point of view it is significant that what Joyce presented as his desk was not a clean slate but a chaotic collection of snippets, not a space to write on, but a space to engage with. During the Crosbys' visit, Joyce pulled out a clipping about the tenor Sullivan, but the suitcase also contained his own drafts. This mix of clippings and drafts in a portable desk served as a kind of creative toolkit. This anecdote illustrates how Joyce's work is a constant interaction of exo- and endogenesis.

\footnotetext{
${ }^{13}$ For a more elaborate discussion of Wyndham Lewis's role in the production-reception feedback loop, see Dirk Van Hulle, James Joyce's "Work in Progress": Pre-Book Publications of Finnegans Wake Fragments (London: Ashgate, 2016 forthcoming).

${ }^{14}$ Caresse Crosby, The Passionate Years: An Autobiography (New York: The Dial Press, 1953), 181-2.
} 
This is the author's version of an article published by Brill in the journal European Joyce Studies 25 (2016), pp. 226-246. Please refer to the published version for correct citation and content. For more information, see http://booksandjournals.brillonline.com/content/books/b9789004319622s016.

\section{The Exogenetic Feedback Loop: Autopoietic Enaction ${ }^{15}$}

Finnegans Wake contains numerous instances of what James S. Atherton has called the book's "awareness of itself as a 'work in progress"."16 To the extent that Finnegans Wake can be read as a work that makes its own writing process thematic, the mechanics of this process can be summarized as a recycling process of "decomposition" followed by "recombination":

Our wholemole millwheeling vicociclometer (...) receives through a portal vein the dialytically separated elements of precedent decomposition for the verypetpurpose of subsequent recombination (FW 614.27-35)

If we apply this to a particular notebook, say notebook VI.B.06, the function of the notebok in this process takes the shape of a hub: the notebook becomes a distribution centre, where pieces of information are gathered and redistributed:

\footnotetext{
${ }^{15}$ In 1991, Francisco J. Varela, Evan Thompson and Eleanor Rosch coined the term "enaction" in a context of cognitive sciences in their book The Embodied Mind, which "questions the centrality of the notion that cognition is fundamentally representation" (9). As they define it, "enaction" denotes the idea that "cognition is not the representation of a pregiven world by a pregiven mind but is rather the enactment of a world and a mind on the basis of a history of the variety of actions that a being in the world performs" (Varela, Thompson and Rosch 1991, 9). As Varela, Thompson and Rosch argue, the notion that cognition is fundamentally representation is based on three assumptions: "The first is that we inhabit a world with particular properties, such as length, color, movement, sound, etc. The second is that we pick up or recover these properties by internally representing them. The third is that there is a separate subjective "we" who does these things" (9). In contrast with this view, Varela, Thompson and Rosch define cognition as "embodied action": "By using the term embodied we mean to highlight two points: first, that cognition depends upon the kinds of experience that come from having a body with various sensorimotor capacities, and second, that these individual sensorimotor capacities are themselves embedded in a more encompassing biological, psychological, and cultural context. By using the word action we mean to emphasize once again that sensory and motor processes, perception and action, are fundamentally inseparable in lived cognition" (172-3). In cognitive philosophy, "autopoietic enactivism" is committed to "the idea that mentality is something that emerges from the self-organizing and self-creating activities of living organisms" (Daniel D. Hutto and Erik Myin, Radicalizing Enactivism: Basic Minds without Content (Cambridge, Massachusetts: The MIT Press, 2013), 32).

${ }^{16}$ James S. Atherton, The Books at the Wake: A Study of Literary Allusions in James Joyce's 'Finnegans Wake' (London: Faber and Faber, 1959), 59.
} 
This is the author's version of an article published by Brill in the journal European Joyce Studies 25 (2016), pp. 226-246. Please refer to the published version for correct citation and content. For more information, see http://booksandjournals.brillonline.com/content/books/b9789004319622s016.

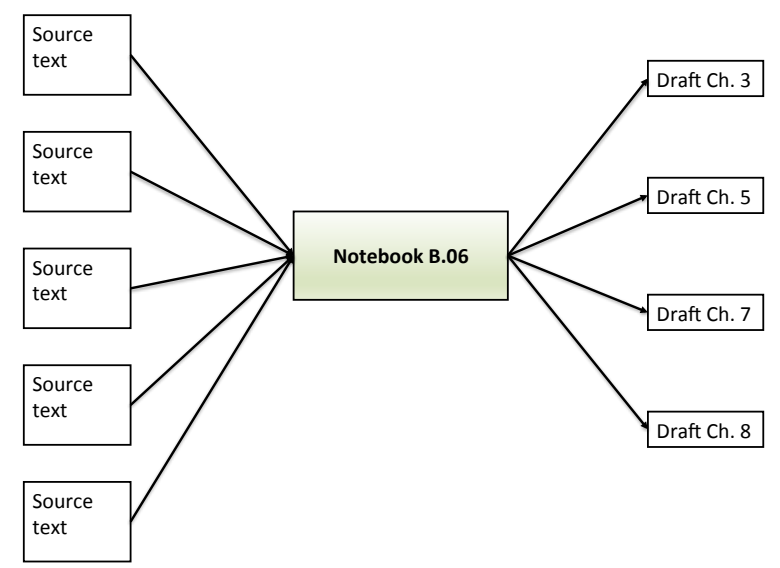

Fig. 1: Decomposition: notebook serves as hub between the sources and the drafts

To use the Wake's own metaphor of the postal service: Joyce was not just a Shem, but also a Shaun, gathering and distributing written documents according to a complex system of postal services. For instance, as a reader of Otto Jespersen's Growth and Structure of the English Language (source discovered by Vincent Deane), Joyce took notes in notebook VI.B.06. He used some notes directly in the 'Guiltless' copybook (crossing them out in his notebook with a colour crayon when he incorporated them in his drafts), but many notes were used indirectly. The undeleted items were copied by France Raphael in 1933 in the C-notebooks, and thence distributed over the so-called 'notesheets' for Book III (the following visualisation does not represent the full complexity of the writing process, but is kept schematic for clarity's sake): 
This is the author's version of an article published by Brill in the journal European Joyce Studies 25 (2016), pp. 226-246. Please refer to the published version for correct citation and content. For more information, see http://booksandjournals.brillonline.com/content/books/b9789004319622s016.

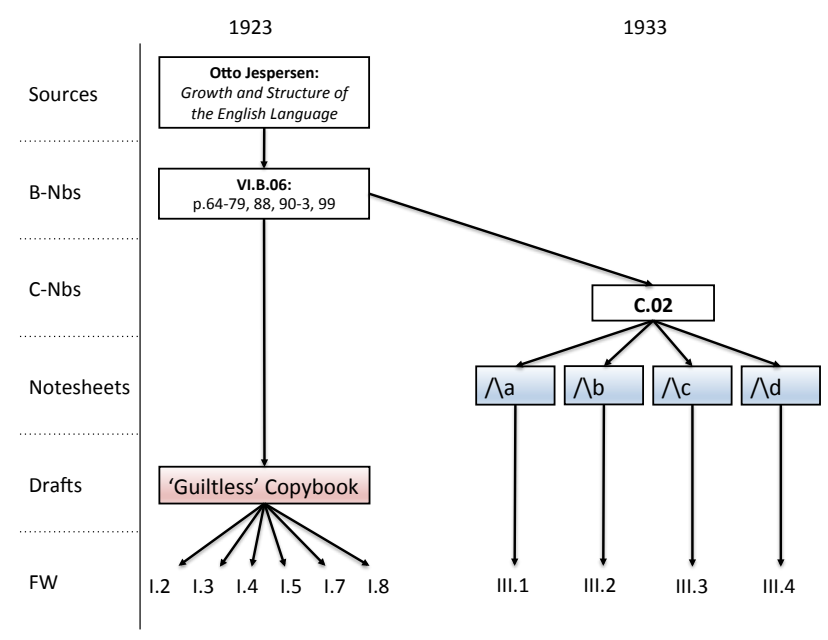

Fig. 2: Joyce's “recombination," indirect usage (via France Raphaël's transcriptions in the C-notebooks and the so-called notesheets)

But of course, this one notebook did not function in isolation. If we zoom in on the direct usage of notes in the "Guiltless" copybook, we can concentrate on an early period, when Joyce had filled only relatively few notebooks. To write the drafts in the "Guiltless" copybook, Joyce used at least seven notebooks:

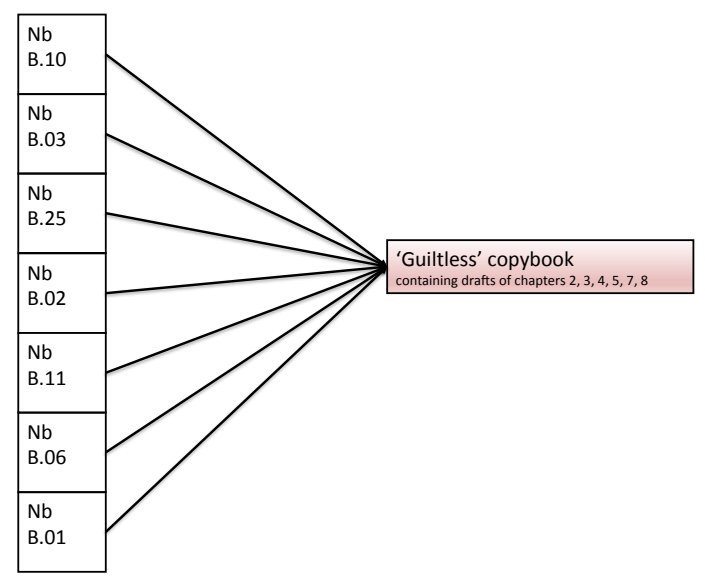

Fig. 3: Joyce's "recombination," direct usage in the "Guiltless" copybook. 
This is the author's version of an article published by Brill in the journal European Joyce Studies 25 (2016), pp. 226-246. Please refer to the published version for correct citation and content. For more information, see http://booksandjournals.brillonline.com/content/books/b9789004319622s016.

About ten years ago, at the Centre for Manuscript Genetics (University of Antwerp), Geert Lernout, Vincent Neyt and I made a prototype of a digital scholarly edition of the "Guiltless" copybook, including the links to the relevant notebooks. By means of this prototype, it is possible to visualize the feedback loop between the reception and production of the text.

\section{The Endogenetic Feedback Loop: The Creative Space of the "Guiltless" Copybook}

Even if a draft is not based on external source texts, the document of the draft also plays a role in the workings of the extended mind. Again, the "Guiltless" copybook serves as a good example. It is remarkable that Joyce kept writing in the same copybook, even when there was hardly any space left. The notebook's role as a socalled "environmental vehicle" was considerable. ${ }^{17}$ The "Guiltless" copybook is the material trace of one of the most creative periods in the genesis of "Work in Progress" and the confined creative space of the copybook seems to have contributed to the intensity of this writing process. Chapter I.5 (sections 1 and 4) - the fragment published in Criterion - is a good example. As a visualization of the sections' entanglement shows, ${ }^{18}$ Joyce wrote section 1 literally around section 2 (the letter, first draft, written on pages 31r, 32r, 33r). Section 1 starts on page 33r, continuing in the margin of $34 \mathrm{r}$, then jumps backward to the open spaces on the pages preceding the Letter $(29 \mathrm{v}-30 \mathrm{r})$ and continues in retrograde direction to page $25 \mathrm{v}$ on the pages that were not filled yet (between and among the first draft of I.4 section 2 and the second draft of I.4 section 1). ${ }^{19}$

Once the letter and its delivery (sections 2 and 3) were extracted and put aside, the analysis stood on its own, without its object of research. This analysis (sections 1 plus 4) is what Joyce sent to T.S. Eliot in February $1925^{20}$ for inclusion in his

\footnotetext{
${ }^{17}$ Richard Menary, 'Introduction', in: The Extended Mind, ed. by Richard Menary (Cambridge, MA, and London: MIT Press, 2010), 1-25, esp. 21. See also Richard Menary, 'Writing as Thinking', Language Sciences 5 (2007), 621-632.

${ }^{18}$ Dirk Van Hulle, "The Writing Sequence of the 'Guiltless' Copybook," Genetic Joyce Studies, Tools \& Queries, 2009, www.antwerpjamesjoycecenter.com/guiltless/index.html

${ }^{19}$ The Centre for Manuscript Genetics at the University of Antwerp is working on a digital edition that visualizes this enactive role of the "Guiltless" copybook as a creative space. This project is part of the project "Literature and the Extended Mind: A Reassessment of Modernism" (TOP BOF project, funded by the University of Antwerp; principal investigator: Dirk Van Hulle).

${ }^{20}$ Richard Ellmann, James Joyce, new and revised edition (Oxford: Oxford University Press, 1983), 574.
} 
This is the author's version of an article published by Brill in the journal European Joyce Studies 25 (2016), pp. 226-246. Please refer to the published version for correct citation and content. For more information, see http://booksandjournals.brillonline.com/content/books/b9789004319622s016.

magazine Criterion, where it appeared in July under the title "Fragment of an Unpublished Work."

Joyce clearly was a writer who "thought on paper." He was also sensitive to whatever happened to offer itself as potential material for his work. He was able to incorporate enormous amounts of external material by means of a process that became thematic in Finnegans Wake, when he described it as "decomposition" for the purpose of subsequent "recombination" (FW 614.34-5). Not unlike Shem the "notesnatcher," he snatched words and excerpts from numerous books in his notebooks, thus decomposing others' texts and recombining them in his drafts. Evidently, these impressions were processed in the writer's mind, but this mind was not limited to the writer's physical brain; it included the interplay with his environment, and the process of conscious recombination proceeded according to what Daniel C. Dennett has described as the "multiple drafts model,"21 which he also referred to as a "Joycean machine in our brains." ${ }^{22}$ This "machine" is not only predicated on Joyce's stream-of-consciousness technique, as Tim Conley notes, but is also akin to "textual-genetic methods of re-reading Joyce," ${ }^{23}$ and Finnegans Wake in particular. Quoting the Wakean phrase "to isolate i from my multiple Mes" ( $F W$ 410.12), Conley argues that "consciousness is not so much a quality as a process, not a given but a work in progress." 24

In the "Guiltless" copybook, this process becomes palpable as it shows the creative and generative potential of Joyce's interaction with the material environment of this copybook. In the study of writing processes this interaction is known as the impact of the "text produced so far" (or TPSF) ${ }^{25}$ on the writing process, since the writer is simultaneously his own reader and this re-reading of the text produced so far keeps informing and colouring the rest of the text that is still to be written. Through the notion of "enaction," this mechanism constitutes an endogenetic (in addition to the

\footnotetext{
${ }^{21}$ Dennett, Daniel C. Dennett, Consciousness Explained (London: Penguin, 1991), 111-43.

${ }^{22}$ Daniel C. Dennett, Sweet Dreams: Philosophical Obstacles to a Science of Consciousness (Cambridge, MA: MIT Press, 2006), 171-72.

${ }^{23}$ Tim Conley, "“Cog it out': Joyce on the Brain,” Joyce Studies Annual 2014, 25-41, esp. 34-5.

${ }^{24}$ Conley, "'Cog it out'," 32.

${ }^{25}$ Linda Flower and John R. Hayes, “A Cognitive Process Theory of Writing," College Composition and Communication 32.4 (1981), 365-87, esp. 370. See also Mariëlle Leijten, Sven de Maeyer and Luuk van Waes, "Coordinating Sentence Composition with Error Correction: A Multilevel Analysis," Journal of Writing Research 2.3 (2011), 331-363, esp. 331.
} 
This is the author's version of an article published by Brill in the journal European Joyce Studies 25 (2016), pp. 226-246. Please refer to the published version for correct citation and content. For more information, see http://booksandjournals.brillonline.com/content/books/b9789004319622s016.

exogenetic) feedback loop, which also fits in with the concept of the "extended mind." The workings of this endogenetic feedback loop, together with the exogenetic feedback loop described above, is what a James Joyce Digital Library can delineate.

\section{The Making of a James Joyce Digital Library: A Rationale}

This extended mind theory is the cognitive philosophy that informs the model of the James Joyce Digital Library as we are developing it at the Centre for Manuscript Genetics. It is conceived as a relational database, and in that sense it differs from the Beckett Digital Library that is part of the Beckett Digital Manuscript Project (www.beckettarchive.org). Joyce's writing was remarkably serendipitous. He could integrate whatever word he happened to encounter. And inevitably this had an impact on the texture of his prose. Beckett's writing is equally intertextual, but the exogenesis is not as directly traceable as in Joyce's case. As a result, we have chosen to adopt two different approaches, adapting the digital infrastructure to the material, or in other words: the material dictates the digital infrastructure. Joyce's notes invite an approach that involves a relational database, starting from the exogenesis.

Beckett's manuscripts require an approach in which the endogenesis is more central, and for which we use TEI-XML. ${ }^{26}$ But in both cases, intensive reading was an inherent part of the writing practice. Whether we try to visualize this by means of a relational database or a genetic edition in TEI-XML is not the core issue. What is important is that the digital infrastructure not only reconstructs the writer's library, but provides a simulation of the cultural and material environment as experienced by the writer.

The empirical basis is relatively small. Compared to other writers, Joyce did not preserve many of his books. The collections at the Harry Ransom Center in Austin, Texas, and the University at Buffalo ${ }^{27}$ constitute only a fraction of what Joyce

\footnotetext{
${ }^{26}$ XML (eXtensible Markup Language), following the guidelines of the Text Encoding Initiative (TEI).

${ }^{27}$ See Thomas E. Connolly, The Personal Library of James Joyce: A Descriptive Bibliography (Buffalo, NY: The University of Buffalo, 1955); Michael Patrick Gillespie, Inverted Volumes Improperly Arranged: James Joyce and His Trieste Library (Ann Arbor, Michigan: UMI Research Press, 1983); http://www.jjon.org/joyce-s-library; the list of "Joyce's Paris library" on James Joyce Online Notes focuses on Ulysses and the earlier works: "The titles below are those texts from Joyce's Paris library which were published before the publication of the first book edition of Ulysses and might therefore be of particular interest to scholars of Ulysses and the earlier works. Books published later, or presented later to Joyce (according to the evidence of inscriptions) are not included." The site also has
} 
This is the author's version of an article published by Brill in the journal European Joyce Studies 25 (2016), pp. 226-246. Please refer to the published version for correct citation and content. For more information, see http://booksandjournals.brillonline.com/content/books/b9789004319622s016.

read. Most of the source texts he consulted to make notes for Finnegans Wake have to be reconstructed on the basis of the notebooks. The resulting "virtual" library implies a large amount of interpretation. One of the dangers of a digital library is the impression it may create that (1) what is presented is all there is, and that (2) all that is presented is of equal calibre in terms of our (un)certainty as to its contribution to "Work in Progress." As de Biasi indicated when elaborating on Debray Genette's terms exogenesis and endogenesis, there is an aspect of exogenesis that might be termed "hypothetical exogenetics": "In the absence of any locatable trace in the work's manuscripts, a highly probable source (for example, the influence of Balzac's Illusions perdues on the writing of L'éducation sentimentale) could become the object of the same kind of study, but under the heading hypothetical exogenetics, in accordance with an analytical procedure that clearly differentiates it from exogenetics per se. ${ }^{28}$ I therefore propose a rough typology of the kinds of reading traces one may encounter and take into account in a digital reconstruction of a writer's (extant + virtual) library, marking the degree of certainty by means of asterisks.

\section{(1) Joyce makes an allusion to a book in his own work: *}

As James S. Atherton has shown in his monograph on the numerous allusions in the Wake, it is perfectly possible that Joyce refers to a book of which there is no trace in the archives or in the correspondence. That does not make the allusion any less real. As Finn Fordham shows (see his essay in this volume), a strong argument can be made for Joyce's use of works by Kipling, even though no reading traces have been preserved in Joyce's personal libraries or his notebooks. With regard to the reconstruction of Joyce's library, these results of "hypothetical exogenetics" would deserve to be included with an asterisk if this inclusion is backed up with an argument such as Fordham's essay.

\section{(2) Joyce mentions his reading of a book in letters or interviews: *}

\footnotetext{
a small section called "Some additional works not listed in Joyce's Trieste library but which he is known to have read or consulted". This section contains three books (by Maurice Fishberg, Giuseppe Giacosa and Marco Praga).

${ }^{28}$ Pierre-Marc de Biasi, “'What is a Literary Draft?’ Toward a Functional Typology of Genetic Documentation," in "Drafts," ed. M. Contat, D. Hollier, and J. Neefs, Yale French Studies 89 (1996), 45.
} 
This is the author's version of an article published by Brill in the journal European Joyce Studies 25 (2016), pp. 226-246. Please refer to the published version for correct citation and content. For more information, see http://booksandjournals.brillonline.com/content/books/b9789004319622s016.

In a letter of 27 January 1925, Joyce told Harriet Shaw Weaver that Sylvia Beach was going to send her "a book of spirit talks with Oscar Wilde" - adding in the simplest terms: "He does not like Ulysses" (Letters I 225). So Joyce tried to neutralize the ghostly criticism by means of his vaccination technique, incorporating a bit of the harmful matter to strengthen the immune system of his "Work in Progress". In this case, there are traces of Joyce's reading, even though the notebook is missing. This missing notebook (VI.D.3) can be partially reconstructed on the basis of France Raphael's transcription in notebook VI.C.4. Between December 1924 and February 1925 Joyce made notes on Hester Travers Smith's Psychic Messages from Oscar Wilde (London: T. Werner Laurie, 1923). ${ }^{29}$ In this book on spiritual messages sent by the ghost of Oscar Wilde to his mediums through automatic writing with the ouija board, Joyce read what "Wilde's spirit" thought of Ulysses:
Yes, I have smeared my fingers with that vast work. It has given me one exquisite moment of amusement. I gathered that if I hoped to retain my reputation as an intelligent shade, open to new ideas, I must peruse this volume. It is a singular matter that a countryman of mine should have produced this great bulk of filth. ${ }^{30}$

Joyce used the words of the attack ("this great bulk of filth") for HCE's defence in a draft of Haveth Childers Everywhere: "Who accuses me. My adversary, the he is the first liar in his of this land. Shucks! Such bughouse filth as I cannot ${ }^{\text {barely }}$ conceive ${ }^{\text {of, }}$ (British Library MS 47482b-113v; JJA 58:094). Wilde's ghost felt that "even I, who am a shade, and I who have tasted the fullness of life and its meed of bitterness, should cry aloud: "Shame upon Joyce, shame on his work, shame on his lying

\footnotetext{
${ }^{29}$ I owe a debt of gratitude to Viviana Braslasu for drawing my attention to this source text. In The Textual Diaries of James Joyce, Danis Rose suggested this book could be the source of the notes (including "ouidja board") on page 186 of notebook VI.B.14. Mikio Fuse discovered that these notes probably derive from another source text, relating to Hester Travers Smith's transcript: Herbert Thurston's article “The 'Oscar Wilde' Script in its Baring on Survival," Studies: An Irish Quarterly Review, vol. 13, Nr. 49 (March 1924), 14-28.

${ }^{30}$ Hester Travers Smith, Psychic Messages from Oscar Wilde (London: T. Werner Laurie, 1923), 17; emphasis added.
} 
This is the author's version of an article published by Brill in the journal European Joyce Studies 25 (2016), pp. 226-246. Please refer to the published version for correct citation and content. For more information, see http://booksandjournals.brillonline.com/content/books/b9789004319622s016.

soul." "31 Joyce incorporated this criticism of his previous book (Ulysses) in his new work, notably in the fair copy of Haveth Childers Everywhere:

It is truly most amusin. There is not one teaspoonspill of evidence to my bad baad as you shall see as this is and I can take off my coats here before those in heaven to enter into my process ${ }^{\text {protestant }}$ caveat against the pupup publication of libel by any Ticks Tipsylon to that hightest personage at moments holding down the throne. Shames upon pipip private $\mathbf{M}-$ ! Shames on his foulsomeness! Shames on his lulul lying sowel!” (MS 47484a-27; JJA 58: 128).

In this case, Joyce's letter to Harriet Shaw Weaver of 27 January 1925 in which he mentions "a book of spirit talks with Oscar Wilde" proved to be quite useful to this exogenetic research. But statements in letters can be very deceptive. For instance, as late as 31 May 1927, Joyce claimed he had "never read" Lewis Carroll's work until a few weeks earlier. ${ }^{32}$ Nonetheless, whatever Joyce claimed in his letters, he did take a greater interest in Carroll's work than he cared to acknowledge as he took dozens of notes on Belle Moses's Lewis Carroll in Wonderland and at Home (New York and London: D. Appleton \& Co., 1910), probably as early as the Fall of $1923 .^{33}$

(3) Joyce's copy of a book is still extant in his personal library or elsewhere,
a. without Joyce's marginalia:
b. with Joyce's marginalia:

a. If there are no marginalia, the mere presence of a book in Joyce's library is no guarantee that he has actually read it. The books from the Trieste library, for instance,

\footnotetext{
${ }^{31}$ Hester Travers Smith, Psychic Messages from Oscar Wilde, 17.

32 "Another (or rather many) says he is imitating Lewis Carroll. I never read him till Mrs Nutting gave me a book, not Alice, a few weeks ago - though, of course, I heard bits and scraps." (Letters I 255) Apart from that, Joyce only mentions Carroll briefly in a letter to Harriet Shaw Weaver of 28 March 1928.

${ }^{33}$ Source discovered by Viviana Mirela Braslasu, Centre for Manuscript Genetics, University of Antwerp. According to Braslasu, Joyce excerpted passages from Moses's book in the missing notebook VI.X.2, which was compiled in December 1923 according to Danis Rose's dating (The Textual Diaries of James Joyce (Dublin: The Lilliput Press, 1995), 26). See Vivana Mirela Braslasu, "Wordpainter and mixer": Oliver Wendell Holmes and Lewis Carroll in Joyce's Finnegans Wake (doctoral dissertation, University of Antwerp, 4 December 2015).
} 
This is the author's version of an article published by Brill in the journal European Joyce Studies 25 (2016), pp. 226-246. Please refer to the published version for correct citation and content. For more information, see http://booksandjournals.brillonline.com/content/books/b9789004319622s016.

are still preserved thanks to Stanislaus Joyce. It is not always possible to determine with certainty whether a book belonged to James Joyce or to his brother. This situation is the rule rather than an exception with regard to writers' libraries in general. For instance, Samuel Beckett's library contains books that possibly belonged to Suzanne Deschevaux-Dumesnil. ${ }^{34}$ And the same goes for non-canonical authors, such as the Flemish author Raymond Brulez, whose library is still preserved at his daughter's house in Brussels, but mixed with the library of his son-in-law. Even if a book contains non-verbal marginalia such as pencil marks or dog-ears, it is not always possible to determine with certainty if these are Joyce's or someone else's. Hence the attribution of only a single asterisk, to indicate the degree of (un)certainty.

b. Joyce may not have been the greatest "marginalist," 35 but he sometimes did mark passages in the margin. An example of such a book is Heinrich Zimmer Jr.'s Maya: Der indische Mythos. The copy of this book in Joyce's library (kept at the University at Buffalo) not only contains three pages of reading notes by Samuel Beckett (taken for Joyce), ${ }^{36}$ but also marginal pencil marks by Joyce. ${ }^{37}$ It was sent to Joyce as a dedication copy by Heinrich Zimmer Jr. himself in early October 1938. Joyce not only marked the copy as a "marginalist," he also acted as an "extractor" - in Daniel Ferrer's terms - making reading notes in two separate notebooks: VI.B. 47: 75-6 (corresponding to pages 1-48 in Zimmer's book) and VI.B.41: 288-9 (corresponding to pages 48-105 Zimmer's book). A few of these notes were processed in "Work in Progress" at a late stage of the genesis, the galley proofs of Book III.3.

\section{(4) Joyce has made reading notes in a separate notebook: **}

As indicated above, Joyce was not a very active "marginalist" but he was a great “extractor” as his Finnegans Wake notebooks evidence. A good example is notebook

\footnotetext{
${ }^{34}$ See Dirk Van Hulle and Mark Nixon, Samuel Beckett's Library (Cambridge: Cambridge University Press, 2014).

${ }^{35}$ Term suggested by Daniel Ferrer, "Un imperceptible trait de gomme de tragacanthe..." in Bibliothèques d'écrivains, ed. Paolo D'Iorio and Daniel Ferrer (Paris: CNRS Editions, 2001), 18. See also Daniel Ferrer, "Towards a Marginalist Economy of Textual Genesis," in Reading Notes (Variants 2/3) ed. Dirk Van Hulle and Wim Van Mierlo (New York and Amsterdam: Rodopi, 2004$), 7$.

${ }^{36}$ Dirk Van Hulle, "Beckett - Mauthner - Zimmer - Joyce," Joyce Studies Annual (1999), 142-83.

${ }^{37}$ Thomas E. Connolly, The Personal Library of James Joyce (Buffalo: Norwood Editions, 1978), $45-$ 7.
} 
This is the author's version of an article published by Brill in the journal European Joyce Studies 25 (2016), pp. 226-246. Please refer to the published version for correct citation and content. For more information, see http://booksandjournals.brillonline.com/content/books/b9789004319622s016.

VI.B.10. It notably contains excerpts from a series of street interviews in the Daily Sketch of 14 December 1922, a source discovered by Vincent Deane. The interviews were part of a petition regarding the trial of Frederick Bywaters, who murdered the husband of his beloved Edith Thompson. He received the death penalty on 9 January 1923, and so did Edith Thompson, as an accessory to the murder. One of the street interviews in the Daily Sketch suggests that she was actually more to blame than Bywaters himself: "Three soldiers were walking together in Fleetstreet: one gave an opinion in which all concurred. It was the woman who was to blame. Bywaters played a bad part in the crime, but he was coerced. He proved himself a man afterwards. $" 38$ After Joyce had excerpted this passage in his notebook (VI.B.10, 71), it took him a year to discover its potential and develop it in his draft of chapter I.3 (in the "Guiltless" copybook): "Three soldiers of the Coldstream Guards were walking in Montgomery street. One gave an opinion in which all concurred. It was the women, they said; he showed himself a man afterwards" (FDV 71; BL MS 47471b, 03r; emphasis added). This was written on the same page of the "Guiltless" copybook as the phrase "The data, did we possess them, are too few to warrant certitude" (BL MS 47471b-03r). In this case, even though Joyce did not keep a copy of the Daily Sketch, the data were enough for Vincent Deane to determine with certitude that this was the source text from which this passage derives.

Joyce's "decomposition" of source texts can be mapped digitally after the model of the Finnegans Wake notebook edition edited by Vincent Deane, Daniel Ferrer and Geert Lernout (Turnhout: Brepols, 2001-), mentioning the full bibliographic address, including the page in Finnegans Wake if the note eventually made it into the published text. To map the "recombination," the "Guiltless" copybook serves as an excellent testing ground. Since the drafts in this copybook were written relatively early in the genesis of Finnegans Wake, Joyce had only filled about seven notebooks with reading notes. In rare cases, such as page $03 \mathrm{r}$ of the "Guiltless" notebook, Joyce relied heavily on one particular notebook (VI.B.10) to write his draft, but even in this case, the double page $02 \mathrm{v}-03 \mathrm{r}$ contains words derived from various notebooks (VI.B.10, VI.B.11 and VI.B.25) - marked with a colour code

\footnotetext{
${ }^{38}$ Quoted in Vincent Deane, Daniel Ferrer and Geert Lernout, The Finnegans Wake Notebooks at Buffalo: VI.B.10 (Turnhout: Brepols, 2001), 10.
} 
This is the author's version of an article published by Brill in the journal European Joyce Studies 25 (2016), pp. 226-246. Please refer to the published version for correct citation and content. For more information, see

http://booksandjournals.brillonline.com/content/books/b9789004319622s016.

in the prototype.

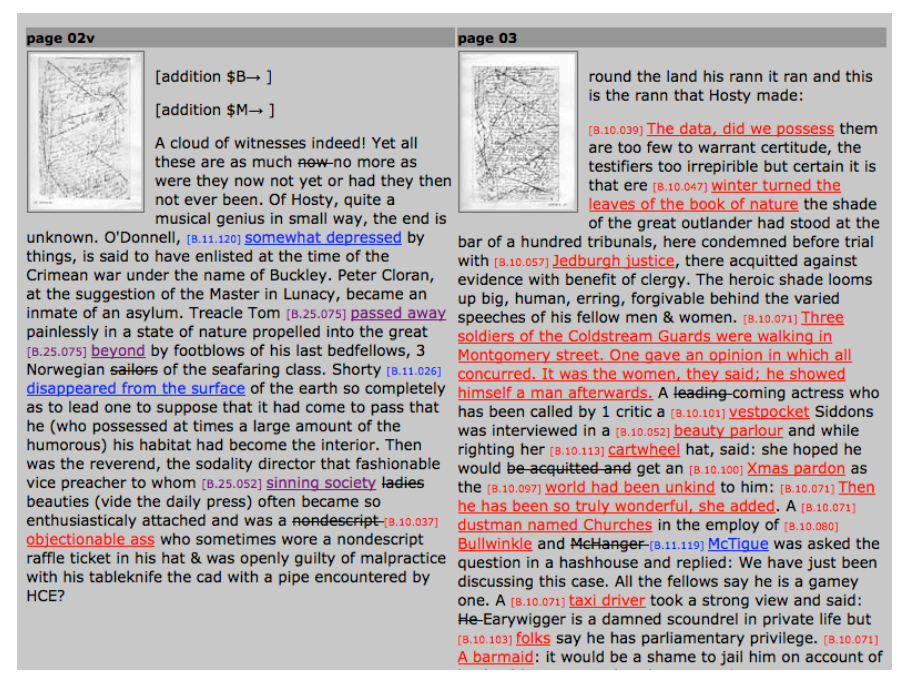

Fig. 4: Prototype of a genetic edition of the "Guiltless" copybook, highlighting the words derived from the notebooks.

The interaction between exogenesis and endogenesis can thus be mapped in an accessible way, and the digital infrastructure has the potential to also include the epigenetic feedback loop between reception and production.

\section{Conclusion}

The reconstruction of a James Joyce digital library is not an exact science. It involves interpretation and probably the proposed criteria will need to be refined when tested on other writers' libraries. But they may already offer some help with regard to the digital reconstitution of Joyce's library. Evidently, this reconstruction is not an attempt to reduce the interpretive possibilities of Finnegans Wake to an empirical basis by determining where Joyce found his inspiration. Instead, the digital architecture of this project presents "Work in Progress" in terms of "autopoietic enaction," involving all the dimensions of literary studies - the text, its production and its reception - and especially the feedback loops among them. 